\title{
Public-private partnership agreements in Romania
}

\author{
by David Stabb and Ligia Popescu
}

Romania is keen to develop public-private partnerships and has recently passed an Ordinance dealing with agreements in this area.

$\mathrm{O}$ ne of the key challenges facing Romania as it seeks to restructure its economy is that large amounts of investment will be required in order to improve basic infrastructure and public services, which the government and local authorities are currently illplaced to fund, given the volume of funding required and the strictures currently being placed on Romania by the IMF as to the size of its budget deficit.

In recent months the Romanian Government has been publicly intimating its willingness to encourage publicprivate partnerships with the private sector and, on 24 January 2002, passed Ordinance 16/2002 on Public Private Partnership Agreements (the 'Ordinance'), whose object is to regulate the 'design, financing, exploitation, maintenance and transfer' of public assets based on a public-private partnership.

The Ordinance is to be completed by methodological norms (the 'norms') drafted by the government, which will be approved by a future Government decision. The norms will establish such matters as: the types of publicprivate partnership projects that there can be; the way in which such projects are to be defined; the form and content of the pre-feasibility and feasibility surveys; the eligibility criteria for investors; the method whereby the project costs and the comparative reference costs are to be computed; the form and content of the project agreement (acord de proiect) and the project contract (contract de proiect); as well as the scheme of risk allocation.

\section{INITIATION AND DEVELOPMENT OF A PUBLIC-PRIVATE PROJECT}

For purposes of the Ordinance, a public-private project has the following features:

(i) it is entirely or principally financed from the own resources of, or resources attracted by, a private investor, based on a public-private partnership model;

(ii) the private investor is willing, independently and based on commercial principles, to cover one or more aspects of the preparation, financing, construction or exploitation of a public asset;

(iii) the outcome of the project will be a public asset.

The initiative to develop a public-private project must come from a public authority, whether (i) the central public authority, in the form of the Romanian Government represented by one or more ministries or authorities or public institutions, which are responsible for public-private projects of national interest or (ii) the authority of the local public administration i.e. the public decision maker responsible for public-private projects of local interest.

The first step is for the promoter (i.e. the authority) to prepare a pre-feasibility study for the public-private project. The public authority is then obliged to publish in Part VI of 'Monitorul Oficial' notice of its intention to start a project based on a public-private partnership, which will set out the conditions relevant to the development of the project. Within 60 days of the publication of the notice of intention to start a public-private partnership, interested investors are entitled to submit letters of intent. Within a further 30 days after this 60 day period, the public authority is obliged to select the best technical, financial and economic offers from amongst the investors submitting letters of intent. If no letters of intent are lodged within the 60-day period, however, the project may be resumed only by restarting the procedure.

The Ordinance envisages a two-stage procedure:

(1) a pre-selection phase, whereby, based on the letters of intent received from the interested investors, the municipality will enter into a project agreement (Acord de proiect) with each of the investors, which have complied with the conditions set out in the originating advertisement published in Monitorul Oficial, and which are selected after the analysis of the letters of intent. A feasibility survey will then be 
prepared in respect of the concepts for the project advanced by each of the investors. The content of the project agreement will be established by the norms, but essentially it will set out the conditions in which the negotiations on development of the project will take place.

Negotiation of the terms of development of the project will be based on the clauses of the project agreement and the pre-feasibility survey, the public authority being required to this end, by order or decision, as applicable, to assign one or several expert commissions to analyse all of the economic, financial, technical and legal issues arising from the project in question. The commission(s) so assigned must then brief the public authority as to the outcome of the negotiation of the project development conditions and make proposals for continuing the negotiations based on the project feasibility survey, which the public authority is required to prepare concurrently with the negotiations with the investors.

The project agreement between the parties must also set out whether it is intended to create a project company or to enter into some other kind of partnership. If a project company is to be used, such company must reside in Romania, operate under Romanian law and have a public-private project as its sole object of activity.

(2) Based on (i) the content of the feasibility survey and (ii) the outcome of the negotiations, the public authority may decide to continue the negotiations with the investors and will then issue a decision ranking the investors based on the 'best offer' criterion in technical, economic and financial terms. This decision must be published in Part III of Monitorul Oficial of Romania. The first ranked party will then continue negotiations to conclude the definitive document, which is defined as the project contract (Contractul de proiect).

An unselected investor is entitled to complain in writing against the authority's decision within 10 calendar days from the publication of the public authority's decision in Monitorul Oficial. In such a case the public authority is obliged to analyse any complaints filed within the deadline and to answer each of them in writing within 10 calendar days from the last day for filing complaints. A more transparent approach would have been to tell the parties whose letter of intent had been declined directly and for the challenge period to run from the date of notification rather than effectively to oblige the unsuccessful parties to monitor Monitor Oficial on a daily basis in order to be able to properly utilise the right to challenge. On the other hand, the approach adopted does assist the concept of having a tight timetable to the development of the public-private project.

\section{THE PROJECT CONTRACT}

When the complaint filing and settlement procedures have been finalised, the public authority, represented by a specifically assigned negotiation commission, will start the final negotiations on the project contract with the top ranked investor. The Ordinance provides that, during the negotiations, the members of the negotiation commission may not be revoked or replaced. Although the intention may have been to prevent the public authority trying to influence the outcome by changing the members of the negotiating commission as it wishes, this way in which the concept has been formulated has the curious effect that it would appear to prevent steps being taken to replace members of the commission who are, for example, found to have conflicts of interest or who or some reason become disabled or unsuitable for service on the commission. It is to be hoped that this will be clarified in due course by the norms.

If the negotiations with the top ranked investor fail to result in a project contract, the public authority must start negotiating in turn with the next ranked offeror until a favourable outcome is reached. If the public authority fails to enter into a project contract with any investor, the whole procedure must be restarted.

The project contract must define precisely the rights and obligations of each party for the entire valid duration of the public-private partnership, covering one or more of the stages of preparation, financing, construction or exploitation of the public asset, over a defined period of time not exceeding 50 years. The State Government or the local government, according to the applicable jurisdiction, must approve the final negotiated version of the project contract.

The form and content of the project contract will be established by the norms, but the ordinance itself establishes the following key principles, which will need to be reflected in the project contract:

(1) The assets resulting from carrying out the project and the land areas occupied by the project may not disposed of, mortgaged, pledged or encumbered for the benefit of third parties during the period of the project contract.

(2) When the purpose of the project contract has been achieved, the project company is obliged to transfer that public property free of charge to the public authority, in a good condition, exploitable and free of any encumbrance or charge.

\section{LAND CONTRIBUTED TO THE PUBLIC- PRIVATE PARTNERSHIP}

The Ordinance contains a number of provisions relating to land contributed by the State to a public-private project (in large part these repeat provisions which are to be found elsewhere in Romanian law) as follows: 
(i) Land areas, corridors and other locations needed for the development of public-private partnership projects are to be delimited based on (a) the urban planning and land development documentation approved in accordance with the laws in force from time to time and (b) the feasibility surveys and the technical projects.

(ii) In relation to public-private projects of national interest, land which is privately owned by the county, county capital, town or rural community or individual or corporate entities can be expropriated in accordance with the provisions of Articles 21-40 of Law No. 33/1994 on Expropriation for Public Projects and will then become public property of the State.

(iii) The Ordinance provides that two categories of land are required to be transferred free of charge to the project company, for management purposes, under a Government decision:

- Land, which is privately owned by the State, on which public-private partnership projects are developed, including land dedicated to installations, buildings and the related facilities; and

- Land, which is publicly owned by the State as a result of expropriation for public-private projects of national interest.

As such, it would appear that the transfer of both private and public lands is envisaged to be in the nature of the grant of a right of administration/ management over land. The right of administration is, however, generally defined as a means of exercise of public ownership by persons other than the usual holders of such right, i.e. the State or the administrative-territorial authorities. Taking into account this definition, the above-mentioned formulation of the Ordinance gives may give rise to a number of potential difficulties:

(a) According to Article 135(5) of the Constitution and Article 12 (1) of the Law 213/1998 of the public patrimony, it appears that the right of administration (in Romanian the identical terminology is used in both the Ordinance and the Constitution) can only be conferred on regies autonomes, on public institutions and on the authorities of the public central or local administration. Such right of administration (i.e. to possess, use and dispose of the public asset) is given to these institutions by the State through an administrative act (i.e. a decision of the Government, of the county or local council, as the case may be, depending upon how assets belong to the public domain of national or of local interest). From this perspective, the grant of an administration right directly to private companies as expressly stipulated in the Ordinance may be debatable.

(b) Equally, concessions and leases, which can be used as alternative structures to make available to the private sector the right to use lands belonging to the State in public or private regime are, almost without exception, subject to detailed competitive tender procedures designed to promote transparency, rather than the comparatively opaque letter of intent procedure envisaged under the Ordinance.

(c) The transfer of the right to administer land is envisaged to be made free of charge, but elsewhere the Ordinance indicates that a usage tariff will be payable by each 'public property user' for accessing the public property and the services used by the project company. The norms will need to establish that the usage tariff will be paid to the operator of the project rather than requiring the operator itself to pay.

(d) The fact that a government decision also appears to be required where land is being made available to a public private project from the private patrimony of a local public authority indicates a potentially high level of centralisation of the process of establishment of public-private partnership projects.

(iv) No taxes or levies shall be charged on such land. It is presumed that this will confer exemption on any transfer of land to the use of a private partner and any municipal or land taxes as may be due from time to time in relation to the land.

\section{INTERACTION WITH OTHER PROVISIONS OF ROMANIAN LAW}

Although the Ordinance specifically provides that contracting public-private partnership projects will not fall under the Government Emergency Ordinance No. $60 / 2001$ on Public Acquisitions, no mention is made of the way in which the Ordinance is intended to interact with the Concession Law 219/1998. The Concession Law already deals with how private sector involvement can be introduced into certain sectors of operation of public assets and services, typically involving larger scale public services and infrastructure assets. As such, it is presumed that the Ordinance is directed at encouraging projects which fall outside the ambit of the Concession Law, and that this will be clarified by the Norms to be issued in due course. The Ordinance does, however, provide that public-private partnership projects will benefit from the legal provisions relating to the promotion of direct investment projects having a significant impact on the Romanian economy 
(essentially involving investments in excess of $\$ 1$ million).

\section{CONCLUSION}

Since the public assets used, and to be developed, under the public-private partnerships envisaged by the Ordinance are not permitted to be mortgaged or pledged, this means that the Ordinance's focus will be on encouraging projects which can generate sufficient revenues to repay the finance for projects conceived in the mould of a build-operate-transfer structure.

However; until the norms are issued, the Ordinance itself will not be sufficient to allow public-private projects to move forward. Equally, the success of this initiative will depend greatly on the workability of the norms and clarification therein of the scope of application of the Ordinance and its exact interaction with other legal models for developing public-private style partnerships, including concessions.

Moreover, there are a number of shortcomings, which may mean that the confidence of investors in such projects will not be sustained:

(1) The transfer of the right of administration of land to the private sector operator is problematic and may be challengeable.

(2) In contrast with other models for public-private partnership, the procedures envisaged by the Ordinance appear to be less formalistic, involving an assessment of letters of intent followed by direct negotiation.

On the one hand, this appears to offer less transparency than alternative structures for publicprivate exploitation of State assets where there are stricter rules based on competitive tender procedures. This is, however, made more serious, when considered against a background of a perception of deep-seated problems in Romania of the corruptibility even of transparent tender procedures.

On the other hand, in the context of Romania being a challenging business environment - it is not uncommon to find that projects offered by way of competitive tender often fail to attract sufficient interest from bidders - and the critical need to attract investment, it could be argued that this procedure has the virtue of offering flexibility and this would appear to be the emphasis, which the Government has chosen to strike.

(3) It will be logistically burdensome for public authorities to conduct a feasibility study with each party submitting a letter of intent. This will involve an unnecessary drain on the authorities' already limited resources.

(4) The centralisation of control over granting rights of administration of land is also likely to be a source of delays and may potentially be used as a back-door veto for projects of which the central authorities do not approve.

(5) Even leaving aside the legal and procedural aspects, many projects may, against the current economic background, not be sufficiently capable of generating revenue to attract investors on a buildoperate-transfer basis. There may be more prospects, if projects were structured on a build-own-operatetransfer structure, but this itself raises difficulties under the constitution as to the delineation of public assets from private assets, where the assets are serving a public function.

The Ordinance, accordingly, represents an interesting development in terms of confirming the political goodwill of the Romanian Government towards encouraging more public-private partnerships and project finance generally, but it will need to be supported by changes to other areas of the law if it is to achieve the objective of encouraging and sustaining public-private partnership projects.

David Stabb and Ligia Popescu

Sinclair Roche \& Temperley 